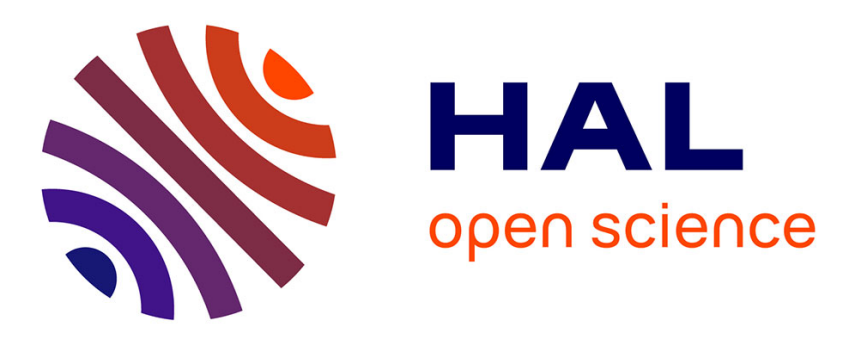

\title{
Synthesis and characterization of Cx-Siy-HA for bone tissue engineering application
}

\author{
Antoine Boyer, David Marchat, Didier Bernache-Assollant
}

\section{To cite this version:}

Antoine Boyer, David Marchat, Didier Bernache-Assollant. Synthesis and characterization of Cx-SiyHA for bone tissue engineering application. Key Engineering Materials, 2013, 529-530, pp.100-104. 10.4028/www.scientific.net/KEM.529-530.100 . hal-00734811

\section{HAL Id: hal-00734811 \\ https://hal.science/hal-00734811}

Submitted on 24 Sep 2012

HAL is a multi-disciplinary open access archive for the deposit and dissemination of scientific research documents, whether they are published or not. The documents may come from teaching and research institutions in France or abroad, or from public or private research centers.
L'archive ouverte pluridisciplinaire HAL, est destinée au dépôt et à la diffusion de documents scientifiques de niveau recherche, publiés ou non, émanant des établissements d'enseignement et de recherche français ou étrangers, des laboratoires publics ou privés. 


\title{
Synthesis And Characterization Of $\mathrm{C}_{\mathrm{x}}-\mathrm{Si}_{\mathrm{y}}-\mathrm{HA}$ For Bone Tissue Engineering Application
}

\author{
Boyer Antoine ${ }^{1, a}$, Marchat David ${ }^{1, b}$ Bernache-Assollant Didier ${ }^{1, \mathrm{c}}$ \\ ${ }^{1}$ Ecole Nationale Supérieure des Mines de Saint-Etienne, CIS-EMSE, CNRS : FRE3312, F-42023 \\ 158 Cours Fauriel, Saint-Etienne, France \\ a anboyer@emse.fr, ${ }^{\mathrm{b}}$ marchat@emse.fr, ${ }^{\mathrm{c}}$ bernache@emse.fr
}

Keywords: co-substituted hydroxyapatite, carbonate, silicate, bioceramics, pellets, aqueous precipitation.

\begin{abstract}
The main goal of this work is to prepare carbon and silicon co-substituted calcium hydroxyapatite $\left(\mathrm{C}_{\mathrm{x}}-\mathrm{Si}_{\mathrm{y}}-\mathrm{HA}\right)$ for bone tissue engineering application. This study includes the synthesis of pure powders with a controlled amount of carbonate (x) and silicate (y) ions within the apatite structure, their characterization with the establishment of database for different compositions, and the manufacture of dense bioceramics. Carbon-silicon co-substituted hydroxyapatite $\left(\mathrm{C}_{0.5}-\mathrm{Si}_{0.5}-\mathrm{HA}\right)$ powders are synthesized by aqueous precipitation. According to structural, spectroscopic and elemental characterizations, silicate and carbonate are included in the apatite lattice and their stoichiometries are controlled. The heat treatments under $\mathrm{CO}_{2}$ atmosphere allow the sintering of pellets without decomposition of the apatite structure.
\end{abstract}

\section{Introduction}

Hydroxyapatite (HA), $\mathrm{Ca}_{10}\left(\mathrm{PO}_{4}\right)_{6}(\mathrm{OH})_{2}$ is the most commonly used bioceramics for dental and orthopedic implants due to its chemical and crystallographic similarities with bone's mineral part. Natural bone is comparable to a badly crystallized apatitic calcium phosphate with substitutions in its lattice. The apatite lattice is very tolerant with substitutions and vacancies [1]. All biological apatites contain carbonate ions in erratic quantities (between 3-8wt \%) [2], filling preferentially in phosphate (B-type) compared to hydroxyl (A-type) positions in the apatite structure [3,4]. The composition depends on bone location, age, sex, etc. [3]. Carbonate substitution in apatite decrease the lattice cristallinity, as well as the temperature of the maximum rate of sintering [5,6], and increase its solubility in biological conditions (in vitro and in vivo) [4]. To improve bioactivity of synthetic grafts as resorption or osteogenesis, the literature talks over incorporation of carbonate or silicate groups in HA. Among trace elements existing in natural bone, silicon show essential characters for bone growth and development [7]. Even if the benefits of soluble silicon have been proved, the bioactivity of silicon substituted hydroxyapatite ceramics was not well defined. Results heterogeneity could be due to uncontrolled composition of Si-HA bioceramics [8]. Adequate solubility of carbonated hydroxyapatite and benefits of soluble silicon could be associated to improve bioactivity of apatite bioceramics. Some studies about carbon-silicon substituted hydroxyapatite were recently published [9-13]. Unfortunately, phase purity was not evidently proved. The main idea of this work was the preparation of a $\mathrm{SiO}_{4}$ and $\mathrm{CO}_{3}$ co-substituted hydroxyapatite bioceramics with controlled stoichiometry for bone tissue engineering. The study was first dedicated to the synthesis of $\mathrm{C}_{\mathrm{x}}-\mathrm{Si} \mathrm{y}-\mathrm{HA}$ powders by aqueous precipitation, and second to the preparation of dense pellets.

\section{Materials and methods}

Synthesis of apatite powders. $\mathrm{C}_{\mathrm{x}}-\mathrm{Si}_{\mathrm{y}}-\mathrm{HA}$ powders were prepared by aqueous precipitation based on the method of Marchat et al [8]. This synthesis method allowed preparing monophasic silicon substituted hydroxyapatite ceramics with controlled composition (e.g. $\mathrm{Si}_{0,5}-\mathrm{HA}$ ). The amount of reagents was calculated assuming silicate and carbonate substitution for phosphate ions according to the following theoretical formula: 


$$
\mathrm{Ca}_{10-\mathrm{x}+\mathrm{y}}{ }^{2+}\left(\mathrm{PO}_{4}{ }^{3-}\right)_{6-\mathrm{y}-\mathrm{x}}\left(\mathrm{SiO}_{4}{ }^{4-}\right)_{\mathrm{y}}\left(\mathrm{CO}_{3}{ }^{2-}\right)_{\mathrm{x}}\left(\mathrm{OH}^{-}\right)_{2-\mathrm{x}+\mathrm{y}} \text { with } \mathrm{x}=\mathrm{y}=0.5
$$

A reagent molar ratio $\mathrm{Ca} /(\mathrm{P}+\mathrm{Si}+\mathrm{C})$ of $10 / 6$ was used. Besides, materials of reference were prepared like a pure $\mathrm{HA}, \mathrm{C}_{\mathrm{x}}-\mathrm{HA}, \mathrm{Si}_{\mathrm{y}}-\mathrm{HA}$ or different $\mathrm{C}_{\mathrm{x}}-\mathrm{Si}_{\mathrm{y}}-\mathrm{HA}$ to establish databases.

A diammonium hydrogen phosphate aqueous solution $\left(\left(\mathrm{NH}_{4}\right)_{2} \mathrm{HPO}_{4}, 99 \%\right.$, Merck, Germany), an ammonium hydrogen carbonate $\left(\left(\mathrm{NH}_{4}\right) \mathrm{HCO}_{3}, 99 \%\right.$, Merck, Germany) and an alkaline silicate solution [8] were added to a calcium nitrate solution $\left(\mathrm{Ca}\left(\mathrm{NO}_{3}\right)_{2}, 4 \mathrm{H}_{2} \mathrm{O}, 99 \%\right.$, Merck, Germany) by means of peristaltic pumps. Deionized water was used to dissolve the reagents. An argon flow (Air Liquide) was maintained on the reactor to prevent any atmospheric uncontrolled carbonation. The $\mathrm{pH}$ was kept at 10.8 by addition of a $28 \%$ ammonia solution (Merck, Germany) using a pH stat (Hanna instrument) and the temperature was regulated automatically at $50^{\circ} \mathrm{C}$ with an external cryothermostat. The suspension was continuously stirred. After complete introduction of reagents, suspension was matured for $48 \mathrm{~h}$, and then filtered on Whatmann filter $(\varnothing>6 \mu \mathrm{m})$. Finally, precipitates were dried at $100^{\circ} \mathrm{C}$ overnight.

Pellets preparation. Protocol consists to precalcine the powders to get a specific surface area around $30 \mathrm{~m}^{2} / \mathrm{g} .160 \mathrm{mg}$ of powder were first uniaxially pressed at $48 \mathrm{MPa}$ in $8 \mathrm{~mm}$ diameter stainless steel die, then isostatically pressed at $300 \mathrm{MPa}$. Lafon et al. studied the synthesis of carbonated hydroxyapatite and their thermal stability under different atmospheres $\left(\mathrm{P}_{\mathrm{CO} 2}, \mathrm{P}_{\mathrm{H} 2 \mathrm{O}}, \mathrm{P}_{\mathrm{N} 2}\right)$ [14,15]. According to their work and a complementary thermal study, it happens a decarbonation of carbonated and silico-carbonated hydroxyapatite powders beyond $800^{\circ} \mathrm{C}$ under air atmosphere $[5,6,14]$. To avoid this decomposition, heat-treatments and sintering of $\mathrm{C}_{0.5}-\mathrm{Si}_{0.5}-\mathrm{HA}$ samples were made under $\mathrm{CO}_{2}$ atmosphere $\left(\mathrm{P}_{\mathrm{CO} 2}=1 \mathrm{~atm}\right)$. Heating rates were fixed at $\pm 5^{\circ} \mathrm{C} / \mathrm{min}$.

\section{Characterizations.}

The crystalline phases of powders were studied using X-ray diffraction (XRD). The device used is a $\theta / 2 \theta$ X-ray diffractometer, Siemens D5000, using $\mathrm{CuK} \alpha$ radiation. The crystalline phases were evaluated on calcined powders over the range $27-38^{\circ}$ with a step size of $0.02^{\circ}$ and a count time of $9 \mathrm{~s}$ by step. Phase identification was performed by comparison to standard patterns from International Center for Diffraction Data - Powder Diffraction Files (ICDD-PDF).

Fourier Transformed Infrared (FT-IR) absorption spectra of powders were performed using a Spectrometer MIR TF VERTEX 70. They were recorded over the range $400-4000 \mathrm{~cm}^{-1}$ with a resolution of $2 \mathrm{~cm}^{-1}$ and with an iteration of 64 successive scans. All spectra were normalized from the $v_{4}$ band of the phosphate group at $600 \mathrm{~cm}^{-1}$ as usual [4].

Calcium, phosphorous and silicon contents of powders were determined by elemental analysis via Inductively Coupled Plasma Atomic Emission Spectrometry (ICP/AES) (Spectrometer HORIBA, Jobin-Yvon, with Activa model). Powders samples were dissolved in nitric acid solution $(\mathrm{pH}<2)$. Likewise, carbon content of powders was determined by an elemental analyzer using an infrared detector (LECO CS-444 carbon and sulfur analyzer).

\section{Results and discussions}

Structural analysis. The XRD patterns of heat-treated (under $\mathrm{CO}_{2}$ ) $\mathrm{C}_{0.5}-\mathrm{Si}_{0.5}-\mathrm{HA}$ powders and $\mathrm{C}_{0.5}-\mathrm{Si}_{0.5}$-HA pellets (Fig. 1) show an apatitic well crystallized structure (PDF 9-432). No secondary crystallized phase is detected, as the main characteristic line of $\mathrm{CaO}$ at $2 \theta=37.347^{\circ}$ (PDF 37-1497). Thus, the decarbonation of B-site, according to the following reaction (Eq. 1) is not observed [14]:

$\mathrm{Ca}_{10}\left(\mathrm{PO}_{4}\right)_{5}\left(\mathrm{CO}_{3}\right)_{0.5}\left(\mathrm{SiO}_{4}\right)_{0.5}(\mathrm{OH})_{2} \rightarrow$

$(11 / 12) \mathrm{Ca}_{10}\left(\mathrm{PO}_{4}\right)_{(60 / 11)}\left(\mathrm{SiO}_{4}\right)_{(6 / 11)}(\mathrm{OH})_{(16 / 11)}+(10 / 12) \mathrm{CaO}+(1 / 2) \mathrm{CO}_{2}+(1 / 3) \mathrm{H}_{2} \mathrm{O}$

The $\mathrm{CO}_{2}$ atmosphere keeps carbonate in apatite lattice and avoids phase decomposition. Thereby, the results indicate that silicon and carbon can be incorporated in the apatitic structure, or in an amorphous phosphate, or both. 


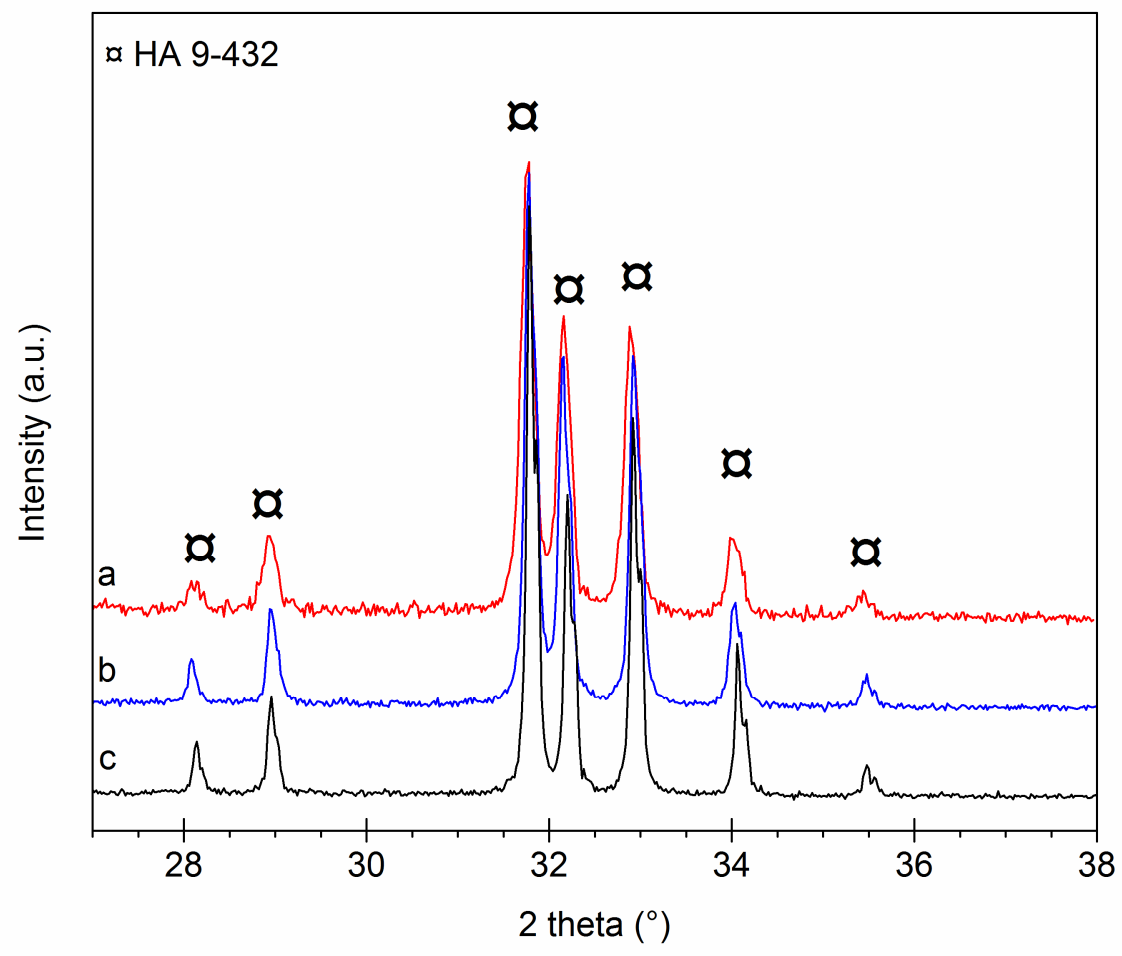

Fig. 1: XRD patterns: (a) $\mathrm{C}_{0.5}-\mathrm{Si}_{0.5}-\mathrm{HA}$ pellets after sintering under $\mathrm{CO}_{2}$; (b) $\mathrm{C}_{0.5}-\mathrm{Si}_{0.5}-\mathrm{HA}$ powders after calcination under $\mathrm{CO}_{2}$; (c) $\mathrm{HA}$ powders in reference after calcination $1000^{\circ} \mathrm{C}-15 \mathrm{~h}$

Spectrometric analysis. The FTIR patterns of $\mathrm{C}_{0.5}-\mathrm{Si}_{0.5}-\mathrm{HA}$ powders and $\mathrm{C}_{0.5}-\mathrm{Si}_{0.5}-\mathrm{HA}$ pellets after heat-treatment under $\mathrm{CO}_{2}$ (Fig. 2) reveal the same main phosphate bands as spectra of heat treated HA under air atmosphere : $472 \mathrm{~cm}^{-1}\left(v_{2}\right), 562$ and $600 \mathrm{~cm}^{-1}\left(v_{4}\right), 959 \mathrm{~cm}^{-1}\left(v_{1}\right), 1015$ and 1080 $\mathrm{cm}^{-1}\left(v_{3}\right)$. Characteristics bands of carbonate groups are shown on spectra of C-Si-HA samples: from B site $\left(872 \mathrm{~cm}^{-1}, 1409 \mathrm{~cm}^{-1}, 1450 \mathrm{~cm}^{-1}, 1466 \mathrm{~cm}^{-1}\right)$, and A site $\left(754 \mathrm{~cm}^{-1}, 878 \mathrm{~cm}^{-1}, 1545 \mathrm{~cm}^{-1}\right)$. The $\mathrm{CO}_{2}$ atmosphere seems enriched the $\mathrm{A}$ sites along the channels in $\mathrm{CO}_{3}$. Indeed, the $v_{\mathrm{S}}$ and $v_{\mathrm{L}}$ modes of hydroxyl group $\left(629 \mathrm{~cm}^{-1}\right.$ and $\left.3572 \mathrm{~cm}^{-1}\right)$ are not observed anymore. More, spectra of $\mathrm{C}_{0.5}-\mathrm{Si}_{0.5}-\mathrm{HA}$ display the specific bands attributed to $\mathrm{SiO}_{4}$ substitution in hydroxyapatite structure: $503 \mathrm{~cm}^{-1}$ $\left(v_{2}: \mathrm{SiO}_{4}\right), 521 \mathrm{~cm}^{-1}\left(v_{4}: \mathrm{SiO}_{4}\right), 750 \mathrm{~cm}^{-1}\left(v_{1}: \mathrm{SiO}_{4}\right), 846 \mathrm{~cm}^{-1}\left(v_{3}: \mathrm{SiO}_{4}\right)$, and $922 \mathrm{~cm}^{-1}(\mathrm{Si}-\mathrm{OH})$ [8]. Besides, an extra band appeared at $945 \mathrm{~cm}^{-1}$. This large band results from the degeneration of $v_{1} \mathrm{PO}_{4}{ }^{3-}$ domain at $960 \mathrm{~cm}^{-1}$ due to the presence of $\mathrm{OH}^{-}$vacancies and $\mathrm{CO}_{3}{ }^{2-}$ ions along the channel in the environment of the phosphate ions. Finally, no evidence of secondary compounds as $\mathrm{CaO}$ or TCP is detected. Likewise, the $\mathrm{SiO}_{2}$ specific bands (e.g. $\sim 680 \mathrm{~cm}^{-1}, \sim 792 \mathrm{~cm}^{-1}$ and $\sim 870 \mathrm{~cm}^{-1}$ [8]) are not observed. To conclude, results prove that $\mathrm{C}_{0.5}-\mathrm{Si}_{0.5}-\mathrm{HA}$ samples (powders and pellets) are monophasics with carbonate and silicate ions localized in the apatitic lattice. 


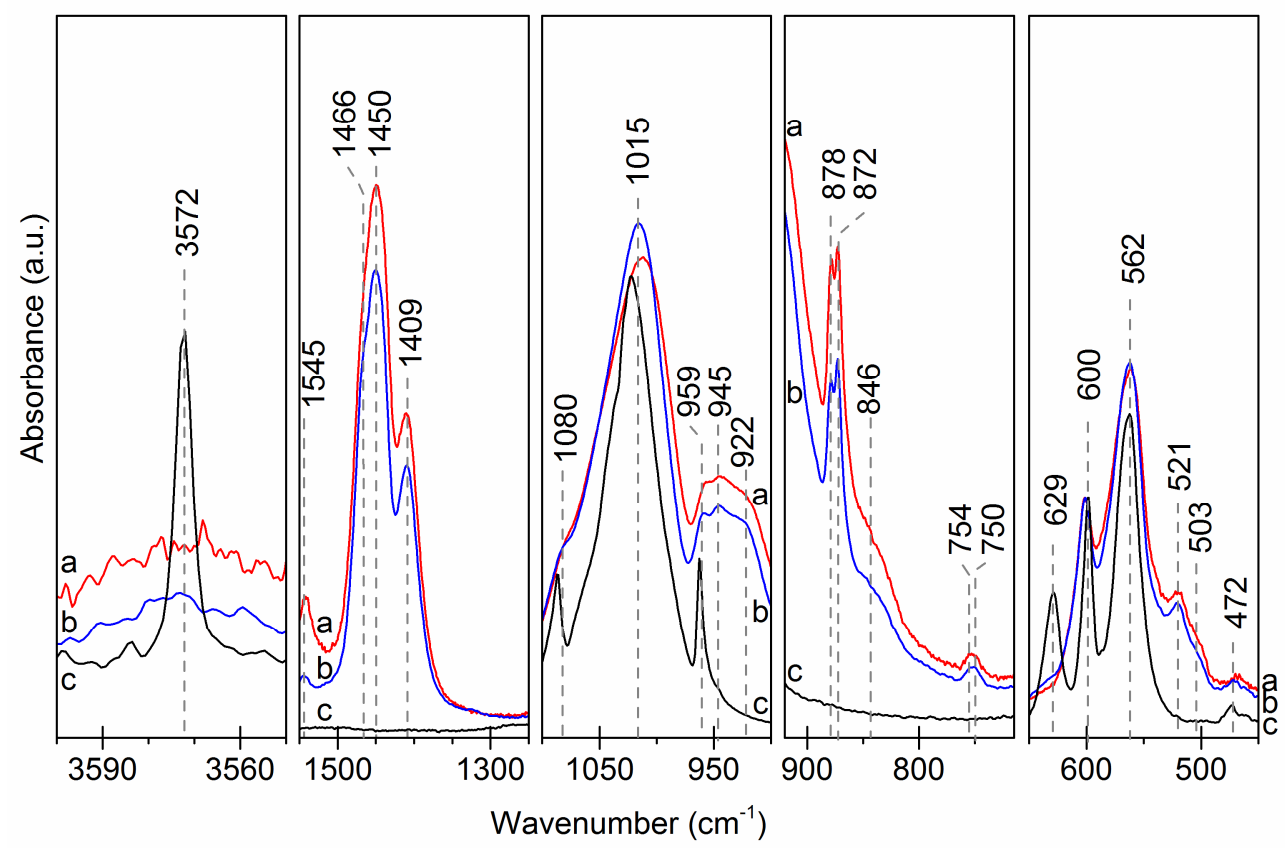

Fig. 2: FTIR patterns: (a) $\mathrm{C}_{0.5}-\mathrm{Si}_{0.5}-\mathrm{HA}$ pellets after sintering under $\mathrm{CO}_{2}$; (b) $\mathrm{C}_{0.5}-\mathrm{Si}_{0.5}-\mathrm{HA}$ powders after calcination under $\mathrm{CO}_{2}$; (c) $\mathrm{HA}$ powders in reference after calcination $1000^{\circ} \mathrm{C}-15 \mathrm{~h}$

Elemental analysis. $\mathrm{C}_{0.5}-\mathrm{Si}_{0.5}$-HA powder and $\mathrm{C}_{0.5}-\mathrm{Si}_{0.5}$-HA pellet elemental compositions were measured after heat treatment at $1000^{\circ} \mathrm{C}$ for $1 \mathrm{~h}$ under $\mathrm{CO}_{2}$ atmosphere (Table 1). The $\mathrm{Ca} / \mathrm{P}$ molar ratios are equal to 1.961 and 2.042 for $\mathrm{C}_{0.5}-\mathrm{Si}_{0.5}$ - $\mathrm{HA}$ powder and pellet respectively. These results are in coherence with the theoretical ratio $\mathrm{Ca} / \mathrm{P}$ of reagent introduced equal to 2 . For the powders and pellets heat treated under $\mathrm{CO}_{2}$ atmosphere, samples present a $\mathrm{Ca} /(\mathrm{P}+\mathrm{Si}+\mathrm{C})$ molar ratios inferior than estimated, respectively 1.546 and 1.567 . In the ideal case of total co-substitution of carbonate and silicate in $\mathrm{B}$ anionic site, the $\mathrm{Ca} /(\mathrm{P}+\mathrm{Si}+\mathrm{C})$ molar ratios for a $\mathrm{C}_{0.5}-\mathrm{Si}_{0.5}-\mathrm{HA}$ composition should be equal to $10 / 6(=1.667)$. Difference can be explained by an increase of carbon amount in compounds, i.e., in A site, due to calcination under $\mathrm{CO}_{2}$ atmosphere. The substitution of $\mathrm{OH}^{-}$by $\mathrm{CO}_{3}{ }^{2-}$ along the channels throughout this heat treatment is confirmed FTIR spectrometry.

Table 1 : Results from elemental analysis

\begin{tabular}{|c|c|c|c|c|}
\hline Compound & Heat treatment & Sintering & $\begin{array}{c}\mathrm{Ca} / \mathrm{P} \\
\text { measured }\end{array}$ & $\begin{array}{c}\mathrm{Ca} /(\mathrm{P}+\mathrm{Si}+\mathrm{C}) \\
\text { measured }\end{array}$ \\
\hline $\begin{array}{c}\mathrm{C}_{0.5}-\mathrm{Si}_{0.5}-\mathrm{HA} \\
\text { powder }\end{array}$ & $1000^{\circ} \mathrm{C}-1 \mathrm{~h}-\mathrm{CO}_{2}$ & $/$ & 1.961 & 1.546 \\
\hline $\begin{array}{c}\mathrm{C}_{0.5}-\mathrm{Si}_{0.5}-\mathrm{HA} \\
\text { pellet }\end{array}$ & $835^{\circ} \mathrm{C}-1 \mathrm{~h}-\mathrm{CO}_{2}$ & $1000^{\circ} \mathrm{C}-1 \mathrm{~h}-\mathrm{CO}_{2}$ & 2.042 & 1.567 \\
\hline
\end{tabular}

\section{Conclusion}

Carbon and silicon co-substituted calcium hydroxyapatite (C-Si-HA) powders were synthesis by aqueous precipitation. Silicate and carbonate were incorporated in the apatite lattice and their stoichiometry was controlled. The heat treatments under $\mathrm{CO}_{2}$ atmosphere allowed the sintering of pellets without decomposition of the apatite structure. Powders and pellets obtained were monophasic apatite polysubstituted with silicate and carbonate ions and free of secondary phase. Studies about the improvement of the sintering conditions are in progress, as well as in vitro and in vivo biological evaluation of dense pellets and scaffolds. 


\section{References}

[1] J.C. Elliott, Structure and chemistry of the apatites and other calcium orthophosphates, Studies in Organic Chemistry, (1994).

[2] F. Driessens, H. Schaeken, R. Verbeeck, On the mechanism of subsitution in carbonated apatites, Journal of Dental Research, 62 (1983) 455.

[3] G. Montel, G. Bonel, J.C. Heughebaert, J.C. Trombe, C. Rey, New concepts in the composition, crystallization and growth of the mineral component of calcified tissues, Journal of Crystal Growth, 53 (1981) 74-99.

[4] C. Rey, B. Collins, T. Goehl, I.R. Dickson, M.J. Glimcher, The carbonate environment in bone mineral: A resolution-enhanced fourier transform infrared spectroscopy study, Calcified Tissue International, 45 (1989) 157-164.

[5] J. Barralet, S. Best, W. Bonfield, Effect of sintering parameters on the density and microstructure of carbonate hydroxyapatite, J. Mater. Sci.-Mater. Med., 11 (2000) 719-724.

[6] Z. Zyman, M. Tkachenko, $\mathrm{CO}_{2}$ gas-activated sintering of carbonated hydroxyapatites, Journal of the European Ceramic Society, 31 (2011) 241-248.

[7] E.M. Carlisle, Silicon: A Possible Factor in Bone Calcification, Science, 167 (1970) 279-280.

[8] D. Marchat, M. Zymelka, L. Gremillard, C. Coelho, L. Joly-Pottuz, F. Babonneau, C. Esnouf, J. Chevalier, D. Bernache-Assollant, Accurate characterization of silicon-substituted hydroxyapatites powders synthesized by a new precipitation route, Acta Biomaterialia, 2012, Submitted.

[9] E. Landi, J. Uggeri, S. Sprio, A. Tampieri, S. Guizzardi, Human osteoblast behavior on as-synthesized $\mathrm{SiO}_{4}$ and B-CO $\mathrm{C}_{3}$ co-substituted apatite, Journal of Biomedical Materials Research Part A, 94A (2010) 59-70.

[10] T. Huang, Y. Xiao, S. Wang, Y. Huang, X. Liu, F. Wu, Z. Gu, Nanostructured Si, Mg, $\mathrm{CO}_{3}{ }^{2-}$ Substituted Hydroxyapatite Coatings Deposited by Liquid Precursor Plasma Spraying: Synthesis and Characterization, Journal of Thermal Spray Technology, 20 (2011) 829-836.

[11] D.M. Ibrahim, A.A. Mostafa, S.I. Korowash, Chemical characterization of some substituted hydroxyapatites, Chem Cent J, 5 (2011) 74.

[12] N.Y. Mostafa, H.M. Hassan, O.H. Abd Elkader, Preparation and Characterization of $\mathrm{Na}^{+}$, $\mathrm{SiO}_{4}{ }^{4-}$, and $\mathrm{CO}_{3}{ }^{2-}$ Co-Substituted Hydroxyapatite, Journal of the American Ceramic Society, 94 (2011) 1584-1590.

[13] N.Y. Mostafa, H.M. Hassan, F.H. Mohamed, Sintering behavior and thermal stability of Na+, $\mathrm{SiO}_{4}{ }^{4-}$ and $\mathrm{CO}_{3}{ }^{2-}$ co-substituted hydroxyapatites, Journal of Alloys and Compounds, 479 (2009) 692-698.

[14] J. Lafon, E. Champion, D. Bernache-Assollant, R. Gibert, A. Danna, Thermal decomposition of carbonated calcium phosphate apatites, Journal of Thermal Analysis and Calorimetry, 72 (2003) 1127-1134.

[15] J.P. Lafon, E. Champion, D. Bernache-Assollant, Processing of AB-type carbonated hydroxyapatite $\mathrm{Ca}_{10-\mathrm{x}}\left(\mathrm{PO}_{4}\right)_{6-\mathrm{x}}\left(\mathrm{CO}_{3}\right)_{\mathrm{x}}(\mathrm{OH})_{2-\mathrm{x}-2 \mathrm{y}}\left(\mathrm{CO}_{3}\right)_{\mathrm{y}}$ ceramics with controlled composition, Journal of the European Ceramic Society, 28 (2008) 139-147.

[16] J. Barralet, J. Knowles, S. Best, W. Bonfield, Thermal decomposition of synthesised carbonate hydroxyapatite, J. Mater. Sci.-Mater. Med., 13 (2002) 529-533. 